\title{
Impact of Critical thinking on Performance in Mathematics among Senior Secondary School Students in Lagos State
}

\author{
Asuai Nelson Chukwuyenum \\ Dept of Educational Foundations, University of Lagos,- Lagos State, Nigeria
}

\begin{abstract}
Critical Thinking has been one of the tools used in our daily life's to solve some problems because it involves logical reasoning, interpreting, analysing and evaluating information to enable one take reliable and valid decisions. The purpose of the study is to examined the impact of Critical thinking on Performance in Mathematics among Senior Secondary School Students in Lagos State. The study would benefit students and teachers by promoting creativity in solving mathematical problems. Quasi-experimental designs was adopted for the study. Multi-stage sampling were applied to generate a sample of 195 students for the study. Mathematics performance test and Watson-glaser Critical Thinking Appraisal were used for the study. Three hypotheses were formulated and tested using Analysis of covariance. The study revealed that there was a significant difference in Mathematics performance test scores among the experimental groups. The study also found out that there was no significance gender difference in Mathematics performance test. Critical Thinking Skills was also an effective means of enhancing students' understanding of Mathematics concepts. It therefore recommended that in teaching Mathematics in secondary schools, Critical thinking skills should be infuse in the curriculum of teachers education so as to improve students' performance in Mathematics.
\end{abstract}

Key words: Critical Thinking, Critical Thinking skill, Gender and Mathematics

\section{Introduction}

The art of calculation is as old as man and Critical Thinking has been one of the tools used in our daily life's to deal with the challenges for survival. On a daily bases people were faced with decisions that require reasoning, understanding, interpreting, analysing and evaluating information before them. This process involves Critical Thinking because it would enable one to take reliable and valid decisions, act ethically, and be able to adapt to changes in any given environment. Critical Thinking is a complex concept that involves cognitive skills and affective dispositions, and this has affected the way some teachers impart the concept to the students. It also appears that some teachers find it difficult to infuse the concept into their teaching so that students can learn not only what to think but also how to think critically, therefore students find it difficult to comprehend the concept and perform below average in mathematics test and examinations.

Critical Thinking requires one's effort to collect, interpret, analyze and evaluate information for the purpose of arriving at a reliable and valid conclusion. In teaching Mathematics in schools, Critical Thinking needs to be integrated and emphasized in the curriculum so that students can learn the skills and apply it to improve their performance and reasoning ability. In this context, if teachers are supposed to infuse Critical Thinking Skills to teach Mathematics in their classrooms, then teacher education programme should also allocate more courses for Critical Thinking so that prospective teachers would become models of thinking strategies who in turn will make the subject easier for the students.

Critical Thinking may also involve logical reasoning and ability to separate facts from opinion, examine information critically with evidence before accepting or rejecting ideas and questions in relation to the issue at hand. In other words, it makes individuals to think, question issues, challenge ideas, generate solutions to problems and take intelligent decisions when faced with challenges (Semil,2006) (1). Critical Thinking also involves deep reasoning and a consideration of what we received rather than a forthright acceptance of different ideas (Mansoor, and Pezeshki , 2012) (1). This means that ideas and suggestions from people about a phenomenon cannot be fully accepted if it does not go through the systematic and logical process of finding the truth, In applying Critical Thinking in school settings, it is necessary to develop thinking skills because people who think Critical would be able to understand the logical connections between ideas, construct and evaluate arguments, detect common mistakes in reasoning and solving problems systematically.

Facione (1990) (1) identified six cognitive skills as central to the concept of Critical Thinking. These were: Interpretation, Analysis, Explanation, Evaluation, Self-regulation and Inference. Critical Thinking Skills therefore, are skills that enable one to analyse and synthesize information to solve problems in broad range of areas (Facione, 1990) (1). In ensuring sound arguments, facts will be collected, analyzed, evaluated and conclusion will be taken based on available facts before them. 
Critical Thinking teaching strategies is an active process in promoting and enhancing students performance in schools. Listening to lectures in the classroom, to most students is a passive activity because students only listening and will not have the opportunity to asks questions when the lectures is going and this makes the class dull. The intellectual skills of Critical Thinking--analysis, synthesis, reflection, etc.--must be learned by actually performing them. Schafersmen (1991) (1)suggests the following Critical Thinking strategies and classroom techniques to school instructors. Classroom instruction, homework, term papers, and examinations. Therefore, the teacher should emphasize students' active intellectual in teaching Mathematics.

Mathematics as an important subject in modern society is useful in schools, workplaces, businesses and for personal decision-making. Mathematics is seen to be a language for everyday use whether in the market place, schools or even at home. Mathematics is fundamental to national prosperity in providing tools for understanding Science, Engineering, Technology and Economics (Kulbir, 2006) (1). The importance of this subject may have led the Nigerian government to make it a compulsory subject in basic education and senior secondary schools as well as a prerequisite for admission to tertiary institutions.

Despite the importance placed on Mathematics by the society, Maduabum and Odili (2006) (1)observed that some students lack interest in the subject and perform poorly in it. For example, the West African Senior Secondary School Certificate Examination (WASSCE) May/June results from 2006 to 2012 show that, on the average, less than $50 \%$ of the students passed Mathematics at credit level. This may be attributed to many factors traceable to the students, teachers, policy makers, content of the curriculum and the quality of the examination. Osarenren and Asiedu (2007) (1) also submitted that the reason for the continued poor performance of students in Mathematics could, among others, be attributed to the students' inability to think critically and analyze Mathematical concepts systematically. This further shows that Critical Thinking is an essential concept that is required to enhance performance in any subject especially in Mathematics.

\subsection{Statement of the Problem}

The traditional way of teaching Mathematics in some Nigerian public secondary schools are teachercentre approach. This method sometimes involves repetition and memorization of previously taught material by filling the students' minds with knowledge of Mathematics without explaining in detail the process of analyzing, evaluating and arriving at a conclusion. In addition, these processes may not make the students to be critical in thinking because some of them might find it difficult to apply the knowledge acquired to solve mathematical problems in a new situation. Critical Thinking Skills has been adopted in Nigeria as one of the nation's educational goals to make students creative. However, it has not been fully incorporated and given wide recognition as one of the major concepts in the school curriculum. Owolabi (2003) (1) explained that the failure rate in Mathematics might be attributed among other reasons to lack of interpreting, explaining, analyzing and evaluating mathematics questions. Therefore the study aim to investigate the impact of Critical Thinking on Academic performance in Mathematics.

\subsection{Theoretical framework}

Cognitive-field theory states that learning process involves constant organization, restructuring, and organization of stimuli elements into a meaningful whole or pattern resulting from many interacting influences in the environment of the learner. Therefore, we should view learning from the perspective of problem solving. Wertheimer (1959) (1) postulates that knowledge is grouped into elements according to the following principles: proximity, similarity/differentiation, closure and simplicity. These principles are called the laws of organization and are used in the context of explaining perception and problem-solving. This theory would be useful to this study because effective learning of Mathematics would be achieved as a result of learners' perception or survey of the problem through the cognitive processes.

Infusion theory stated that traditional curriculum material should be restructured to integrate teaching for thinking into subject area so that students would be aware of the skills, understand it, practise and apply it in other context. In other words, if the teaching of thinking is explicit in subject area it would have a great impact on the students' performance. Swarzts and Perkins (1994) (1) identified various ingredients in Infusion Theory as reliability, causal explanation, argument analysis and the use of evidence for inferences. This theory is relevant to this study because it makes the students understand and learn the content and subject better, interpret meaning of concepts, understand logical structure, detect fallacious arguments and improve academic performance in Mathematics.

\subsection{Significance of the study}

Curriculum developer and policy makers in the education industry would benefit by helping them to review the present educational policy and curriculum with the aim of introducing Critical Thinking Skills as a core component of higher thinking skills development in Mathematics to improve students' learning abilities. The information gathered in this study would also help teachers, institutions and researchers in education to 
have a better understanding of Critical Thinking which would enable them evaluate students' performance in Mathematics more appropriately.

\subsection{Research hypotheses}

The following three research hypotheses are formulated and tested:

1. There is no significant difference in post-test scores in Mathematics Performance Test among students exposed to training on Critical Thinking Skills and those in the control group.

2. There is no significant difference in post-test Critical Thinking Skills scores of students exposed to training and those in the control group.

3. There is no significant difference in post-test scores of Mathematics Performance Test of students due to gender and experimental conditions.

\subsection{Limitation of the study}

The study was carried out in Lagos State, which is located in South west region of Nigeria in West Africa. The study was limited to selected senior secondary school two (SSII) students from public schools in Lagos state

\section{Literature Review}

Scott and Markert (1994) (1) tested Critical Thinking Skills in medical students using the WatsonGlaser Critical Thinking Appraisal and found that Critical Thinking Skills correlated with students' academic success in the first two years of medical school and with MCAT scores. They concluded that Critical Thinking Skills are factor involved in a student's success in the first two years of medical school. Moreover, Marcut (2005) (1) supported that that students who received training in Critical Thinking Skills significantly improved positively in their performance than those who were not trained. More so, Fisher, (2003) (1) highlighted that the Critical Thinking Skills training had helped in stimulating students intellectual capability and make them engaged more in classroom activity. Contrary to this view, Barry, Ada and Jenny (2003) (1)in respect to analysing Critical Thinking Skills, administered CAT Critical Thinking test as pre-test/post-test to two different courses in the social sciences, with the consent of the instructors. 16 students in the control group took both the pre-test and the post-test. No significant change was observed in the performance of students between the pretest and post-test.

Charles, Renae and Rospond (2004) (1) also did a research on Critical Thinking instruments to assess Pharmacy students' Critical Thinking Skills and dispositions, and to identify areas for curriculum reforms. They found out that those in the training group that received training on Critical Thinking Skills did better in their post test scores than their control group counterparts. They were of the view that the training programme on Critical Thinking Skills organized for the training group had a significant impact on them than their control group counterpart who did not received any training programme.. Bassey, Joshua and Asim (2008) (1) carried out a study on gender and Mathematics Achievement in secondary schools in Calabar, Cross Rivers State. The result of their findings revealed that there is a significant difference between the Mathematics achievement of the male and female students.

\subsection{Research design}

\section{Methodology}

The research designs for this study was Quasi-experimental pre-test/ post test control group design. It consists of two experimental groups. One group exposed to training on Critical Thinking and the other group not exposed to training.

The population for this study was SS11 students from selected schools in Lagos metropolis.

\subsection{Sample and Sampling Procedure}

Simple random sampling was used to select Surulere local government out of official twenty local government in Lagos state. Four public Senior Secondary Schools in Surulere were selected through Hat and Draw methods. In selecting the schools all the Senior Secondary schools in Surulere zone were first stratified into three groups- Co-educational, boys' school and girls' school. From the four schools, two of them were selected through hat and draw method for the Training Group, while the other two schools were used for the Control Group. The stratified random sampling technique was used to obtain 195 SSII students consisting of 113 males and 82 females. The stratification was based on school type and gender.

\subsection{Research Instruments}

Three instruments were used for this study. They are as follows: 
1. Personal Data Questionnaire (PDQ): This was designed by the researcher to generate the participants' bio-data which include: gender, school type, class type, and age.

2. Mathematics Performance Test (MPT): Parallel form of Multiple Choice item tests and theory were developed by the researcher using past WAEC question papers from 2006 to 2011. The form consisted of 50items which attracted 50 marks, each with 4 options. The items covered only the topic studied during the training period and it has a high stability co-efficient of 0.87 at 0.05 level of significance when tested during the pilot study.

\section{Watson-Glaser Critical Thinking Appraisal (1980) (1)}

Watson-Glaser Critical Thinking Appraisal is a test of Critical Thinking. It measures high level of reasoning and relevant to problem solving and decision-making. This is a 40-item multiple choice tests. It is designed to measures five sub areas of Critical Thinking which are inference, recognition of assumptions, deduction, interpretation and evaluation of arguments. The possible options range from two to five depending on the questions. Each item has only one correct answer. The concurrent validity of the instrument was 0.61 while reliability coefficient using split-half method was 0.75 . The alpha reliability of the subscales range from 0.31 to 0.83 . The researcher adapted this instrument and later selected 16-items for the main study. The maximum score for W-GCTA is 56 while the minimum score is 16 . A test-retest reliability of 0.73 was obtained within two weeks interval.

\section{Phase 1: Administration of Instruments}

- Intimating the participants with the purpose of the training.

- Administration of all research instruments.

- The researcher used Research Assistants for the distribution and collection of the instruments.

Phase 2: Training for Critical Thinking Skills

There were two experimental groups namely: One Training Group and one Control Group.

The researcher prepared lesson notes and infused Critical Thinking Skills on each of the topics for the Training group and a normal lesson note for the Control group. Meetings were held with each group twice a week for eight weeks. Each session lasted for $1 \mathrm{hr} 20$ minutes.

- Teacher introduce the topic (Sequence and Series) to the participants using prepared lesson notes with Instructional Materials and infuse Critical Thinking Skills to teach the topics. These skills are: These skills includes: Interpretation, Explanation, Analysis, Evaluation., Inferential and Self-regulating skills.

FIG 1: Infusion of Critical Thinking Skills and Sequence and Series in Mathematics lesson plan

\begin{tabular}{|c|c|c|c|}
\hline $\begin{array}{l}\text { Critical } \\
\text { Thinking } \\
\text { Skills }\end{array}$ & OBJECTIVES & TEACHERS ACTIVITIES & STUDENTS ACTIVITIES \\
\hline $\begin{array}{l}\text { Interpret } \\
\text { ation } \\
\text { Skills }\end{array}$ & $\begin{array}{l}\text { To develop skills in } \\
\text { comprehending and expressing } \\
\text { the meaning of data, rules, } \\
\text { procedures, event and } \\
\text { information. E.g Sequence and } \\
\text { series. } \\
\text { 1.Determine the pattern of a } \\
\text { sequence } \\
\text { 2.Determine any particular } \\
\text { terms of a given sequence. } \\
\text { 3.Find the nth term of AP } \\
\text { 4.Find the common difference } \\
\text { and the number n of the terms } \\
\text { of an AP } \\
\text { Find the } 20^{\text {th }} \text { term of an } \\
\text { Arithmetic progression } 3,0,- \\
3-6 \ldots\end{array}$ & $\begin{array}{l}\text { Teacher helps students to identify skills in } \\
\text { interpreting questions, data, rules, procedures, } \\
\text { situations, experiences and beliefs through } \\
\text { (i)categorization (ii) decoding information } \\
\text { and (iii) clarifying meaning. Eg. Find the } 20^{\text {th }} \\
\text { term of an Arithmetic progression } 3,0,-3- \\
6 \ldots \text { This questions will be interpreted by } \\
\text { looking for the difference of the } 1^{\text {st }}, 2^{\text {nd }}, 3^{\text {rd }} \\
\text { figure in that order. Then if the difference is } \\
\text { the same all through, it means the sequence is } \\
\text { AP. Teacher later stated the formular as : } T_{n}= \\
\text { a+ (n-1)d. Where a is first term }=3, \mathrm{~d} \text { is the } \\
\text { difference }=-3 \text { and nth is the number we are } \\
\text { looking for. }\end{array}$ & $\begin{array}{l}\text { Students were able to } \\
\text { interpret data, questions and } \\
\text { statement on Sequence and } \\
\text { series (AP) through } \\
\text { categorizing information, } \\
\text { decode information and } \\
\text { clarifying meaning. Students } \\
\text { were able to subtract } 1^{\text {st }}, 2^{\text {nd }} \text {, } \\
3^{\text {rd }} \text { figures as arrange in either } \\
\text { ascending or descending } \\
\text { order. E.g } 3-0=3 \text {. Again they } \\
\text { were able to state the formula } \\
\text { of A.P. }\end{array}$ \\
\hline $\begin{array}{l}\text { Analysis } \\
\text { skills }\end{array}$ & $\begin{array}{l}\text { To develop skills for detailed } \\
\text { examination of information, } \\
\text { questions, statement and } \\
\text { concepts. } \\
\text { To develop skills in identify } \\
\text { intended and actual inferential } \\
\text { relationship among statements, }\end{array}$ & $\begin{array}{l}\text { Teacher assists the students in breaking down } \\
\text { materials, statements, questions and concepts } \\
\text { into component elements or parts such that its } \\
\text { organizational structure would clearly be } \\
\text { understood through (i) examining ideas and } \\
\text { (ii) detecting arguments. Teacher analyse the } \\
\text { information by introducing the figures into } \\
\text { the formular. T2 } 2=\mathrm{a}+(20-1) \mathrm{d}=19 \mathrm{~d} \text {. }\end{array}$ & $\begin{array}{l}\text { Students were able to } \\
\text { examining ideas and } \\
\text { detecting arguments by } \\
\text { showing workings and steps } \\
\text { in arriving at the answer. E.g } \\
\text { T20 }=\mathrm{a}+(20-1) \mathrm{d}=19 \mathrm{~d} . \\
\mathrm{T} 20=3+19 \mathrm{x}-3 \text {. } \\
\mathrm{T} 20=3-57=-54 .\end{array}$ \\
\hline
\end{tabular}




\begin{tabular}{|c|c|c|c|}
\hline & questions and concepts. & $\begin{array}{c}\text { T20 } 23+19 \times-3 \\
\text { T20 }=3-57=-54\end{array}$ & \\
\hline $\begin{array}{l}\text { Evaluati } \\
\text { on Skills }\end{array}$ & $\begin{array}{l}\text { To develop skills in assessing } \\
\text { or judging the credibility or } \\
\text { value of statements and } \\
\text { methods for given purpose in } \\
\text { relation to rules, principles and } \\
\text { procedures. }\end{array}$ & $\begin{array}{l}\text { Teacher helps the students to evaluate } \\
\text { information, statements and questions through } \\
\text { (i)assessing claims and (ii) assessing } \\
\text { arguments. The teacher assessed the results of } \\
\text { the question asked by critically looking at the } \\
\text { method, procedures use and whether it } \\
\text { logically follows the rules guiding arithmetic } \\
\text { progression.E.g. stating the A.P formula and } \\
\text { ensure that the steps applied followed the } \\
\text { rules of A.P. }\end{array}$ & $\begin{array}{l}\text { Students were able to } \\
\text { evaluate the question by } \\
\text { answering the questions } \\
\text { raised by the teacher and } \\
\text { followed steps by steps } \\
\text { methods of arriving at the } \\
\text { answer }\end{array}$ \\
\hline $\begin{array}{l}\text { Inferenti } \\
\text { al Skills }\end{array}$ & $\begin{array}{l}\text { To develop skills in drawing } \\
\text { reasonable conclusions from } \\
\text { data, statement, judgement, } \\
\text { questions and concepts. }\end{array}$ & $\begin{array}{l}\text { The teacher assists the students to take } \\
\text { relevant decision using evidence and } \\
\text { conjecturing alternatives. Teacher draw } \\
\text { reasonable conclusion by considering that the } \\
\text { question was solved through systematic } \\
\text { approach by applying A.P formula and that } \\
\text { the result obtained is justified: T20 }=3-57 \\
=-54 \text {. }\end{array}$ & $\begin{array}{l}\text { The students were able to } \\
\text { draw relevant conclusion by } \\
\text { following the procedure to } \\
\text { arrive at the answer. }\end{array}$ \\
\hline $\begin{array}{l}\text { Explanat } \\
\text { ion Skills }\end{array}$ & $\begin{array}{l}\text { To develop skills that help } \\
\text { students state the results of } \\
\text { one's reasoning, justify the } \\
\text { reasons in terms of evidential, } \\
\text { conceptual and methods use } \\
\text { in arriving at conclusions. }\end{array}$ & $\begin{array}{l}\text { Teacher helps the students to interpret and } \\
\text { analyze questions, statement and justify the } \\
\text { reasons and methods of arriving at a } \\
\text { conclusion through (i) stating results (ii) } \\
\text { justifying procedures and (iii) presenting } \\
\text { arguments. }\end{array}$ & $\begin{array}{l}\text { The students were able to } \\
\text { expanciate on the topic taught } \\
\text { as well as procedures adopted } \\
\text { for each of the topics. }\end{array}$ \\
\hline $\begin{array}{l}\text { Self- } \\
\text { regulatio } \\
\text { n } \\
\quad \text { Skills }\end{array}$ & $\begin{array}{l}\text { To develop skills that will } \\
\text { make students monitors one's } \\
\text { cognitive activities with a view } \\
\text { of and correcting one's self. }\end{array}$ & $\begin{array}{l}\text { Teacher assists students to apply skills in } \\
\text { reassessing one's judgment through (i)self- } \\
\text { examination and (ii) self-correction. }\end{array}$ & $\begin{array}{l}\text { The students were able to } \\
\text { reassessed their work by } \\
\text { cross checking the } \\
\text { procedures and the answers } \\
\text { they got. }\end{array}$ \\
\hline
\end{tabular}

Topic: Series and Sequence (Arithmetic Progress

- Teacher gave participants room for questions in areas not clear and later responded.

- Evaluation: Teacher asked participants to solve questions relating to Arithmetic progression. E.g. Find the $5^{\text {th }}$ and $8^{\text {th }}$ terms of the sequence whose nth terms is $\quad \begin{array}{ll}\text { (a) } 2 n+1 & \text { (b) } 3-5 n \text {. }\end{array}$

- Teacher collected the scripts, explained further on how to answer difficult areas in the questions and marked students scripts.

- Teacher gave out assignments to the participants on Arithmetic Progression.

\section{Phase 3: Post-test}

Week 8: The researcher revised the training process of Critical Thinking with the participants and later administered the instruments for post-test.

Training for the Control Group

The participants were taught the same topics for the same duration as the experimental group by the researcher but did not receive the Critical Thinking. In addition, normal weekly class tests were conducted and in the eighth week, post tests were administered.

\section{Data Analysis And Presentation}

4.1 Testing of Hypotheses

Hypothesis One: There is no significant difference in post-test scores in Mathematics Performance Test among students exposed to training on Critical Thinking Skills and those in the control group.

Table 1: ANCOVA Test of Difference in Post-test Mathematics Performance between Training and Control Groups.

\begin{tabular}{lcccccc}
\hline Source & \multicolumn{1}{c}{ Type 111 Sum of Squares } & df & \multicolumn{1}{c}{ Mean of Squares } & F & Sig \\
\hline Corrected Model & 11704.50 & 2 & 5852.25 & 72.91 & .000 \\
Covariates & 482.16 & 1 & 482.16 & 6.00 & .015 \\
Experimental Group & 11283.73 & 1 & 11283.73 & 140.58 & .000 \\
Error & 15410.54 & 192 & 80.263 & & \\
Corrected Total & 27115.04 & 194 & & &
\end{tabular}


*Significant at $0.05 ; \mathrm{df}=1 \& 192$

The ANCOVA results presented in Table 1 shows that for the Experimental condition, the F-value obtained was 140.58 as P-value $<0.005$, given 1 and 192 degrees of freedom at the .05 level of significance. This therefore suggests that training on Critical Thinking was effective in improving the Mathematics performance of the students. Therefore hypothesis 1 was rejected. This also showed that Critical Thinking Training had impact on the participants than their Control Group counterparts.

Hypothesis Two: There is no significant difference in post-test scores of Critical Thinking Skills Test among students exposed to the training and those in the control group.

Table 2: ANCOVA Test of Difference in Post-test Critical Thinking Skills between Training and Control Groups.

\begin{tabular}{lccccc}
\hline Source Type III Sum of Squares & df & Mean of Squares & F & Sig \\
\hline Corrected Model & 1562.98 & 2 & 781.49 & 53.22 & .000 \\
Covariates & 743.82 & 1 & 743.83 & 50.65 & .000 \\
Experimental Group & 683.47 & 1 & 683.47 & 46.54 & .000 \\
Error & 2819.28 & 192 & 14.68 & & \\
Corrected Total & 4382.28 & 194 & & & \\
\hline
\end{tabular}

* Significant at $0.05 ; \mathrm{df}=1 \& 192 ;$ F-critical $=3.89$

The ANCOVA results presented in Table 2 shows that for the Experimental condition, the F-cal value obtained was significant at 46.54 as P-value is $<0.05$, given 1 and 192 degrees of freedom at the .05 level of significance. The hypothesis was rejected. This therefore suggests that Critical Thinking Skills training was effective in improving students' performance.

Hypothesis Three: There is no significant difference in post-test Mathematics Performance scores of students due to gender and experimental conditions.

Table 3: 2 × 2 ANCOVA Tests of the Effects of Experimental Condition and Gender on Post-test Mathematics Performance of Students

\begin{tabular}{lccccc}
\hline \multicolumn{1}{l}{ Type III Sum of Squares } & df & Mean of Squares & F & Sig \\
\hline Corrected Mode & 11951.68 & 4 & 2987.92 & 37.43 & .000 \\
Covariates & 481.71 & 1 & 481.71 & 6.03 & .015 \\
Gender & 227.09 & 1 & 227.09 & 2.64 & .093 \\
Experimental Group & 11031.43 & 1 & 11031.43 & 138.22 & .000 \\
Gender/ Experimental & 8.305 & 1 & 8.305 & 0.104 & .747 \\
Error & 15163.34 & 190 & 79.80 & & \\
Corrected Total & 27115.04 & 194 & & & \\
\hline
\end{tabular}

*Not significant at $0.05 ;$ df $=1$ \& $190 ;$ F-critical $=3.89$

Table 3 shows that a calculated F-value of 2.64 for gender was not significant at 0.05 level of significance with degree of freedom 1 and 190 because P-value $>0.05$, Moreover the calculated f-value of 0.104 for interaction effect was not significant at 0.05 level of significant with degree of freedom 1 and 190 because Pvalue $>0.05$. However, F-value of 138.22 for experimental condition was significant at 0.05 with degree of freedom 1 and 190 since P-value is $<0.05$. Hypothesis three was therefore accepted. It was concluded that the post-test Mathematics Performance scores of male and female students in the training and control groups does not significantly differ. This also showed that male students did not do better in Mathematics post-tests tests than their female counterparts.

\section{Discussion Of Findings}

The findings in hypothesis one showed that there was a significant difference in post test Mathematics scores between the Training and Control Group. The reason for the difference could be attributed to acquisition of knowledge in Critical Thinking Skills which were infused in the teaching of Mathematics. Scott and Markert (1994) (1) tested Critical Thinking Skills in medical students using the Watson-Glaser Critical Thinking Appraisal and found that Critical Thinking Skills correlated with students' academic success in the first two years of medical school and with MCAT scores. They concluded that Critical Thinking Skills are factor involved in a student's success in the first two years of medical school. Moreover, Contrary to this view, Barry, Ada and Jenny (2003) (1) in respect to analysing Critical Thinking Skills, administered CAT Critical Thinking test as pre-test/post-test to two different courses in the social sciences, with the consent of the instructors. Both courses were for junior level classes. The pre-test and the post-test were scored by the same group of faculty, from a broad spectrum of disciplines. 16 students in the control group took both the pre-test and the post-test. No significant change was observed in the performance of students between the pre-test and post-test. 
The findings in hypothesis two showed that there was a significant difference in post test Critical Thinking Skills scores between the Training and Control Group. The reason for the difference could be attributed to acquisition of knowledge in Critical Thinking Skills which has aided the training group. Charles, Renae and Rospond (2004) (1) also did a research on Critical Thinking instruments to assess Pharmacy students' Critical Thinking Skills and dispositions, and to identify areas for curriculum reforms. They found out that those in the training group that received training on Critical Thinking Skills did better in their post test scores than their control group counterparts. The reason for the improvement was that they had training on Critical Thinking Skills and were exposed to process of Critical Thinking skills as well as how to take valid and reliable decisions when face with such challenges

The findings in hypothesis three revealed that there was no significant difference in post-test Mathematics Performance of students in the two experimental groups due to their gender. This can be attributed to the awareness of the importance of the subject by both sexes in the society and that one hardly survives without it. The result of the statistical analysis of data showed that the post-test Mathematics Performance of male and female students in the Training and Control Groups significantly differ. Bassey, Joshua and Asim (2008) (1) carried out a study on gender and Mathematics Achievement in secondary schools in Calabar, Cross Rivers State. The result of their findings revealed that there is a significant difference between the Mathematics achievement of the male and female students. This was attributed to environmental factor and also the male students show greater interest in calculation oriented subjects like Mathematics, Physics, Further Mathematics, Chemistry, Accounting or Economics while their female counterparts showed little or no interest in subjects that are calculation oriented but show greater interest in subjects that are literary oriented such as English Language, Christian/Islamic religion knowledge, History and Literature in English.

Abiam and Odok (2006) (1) also carried out a study on gender and Mathematics and found no significant relationship between gender and achievement in number and numeration, algebraic processes, and statistics. They however found the existence of a weak significant relationship in geometry and trigonometry. Also, Adedayo (2006) (1) found no significant difference between the scores of male and female students in Mathematics tests. The gender balance in Mathematics was as result of the interest and attitude as well as the Critical Thinking Skills and Peer Assessment training received by those in the training group.

\subsection{Conclusion}

In the light of the preceding discussions and summary of findings, the following conclusions can be drawn:

1. There was a significant difference in Mathematics performance post-test scores among the experimental groups.

2. There was no significance difference due to gender in post-test scores of Mathematics performance test among the participants.

3. Critical Thinking Skills was an effective means of enhancing students' understanding of Mathematics concepts because the skills has helped in interpreting, analysing, evaluating, and presenting date in a logical and sequence manner.

\subsection{Recommendations}

Based on the findings of this study, the following specific recommendations are put forward for consideration:

1. Training in Critical Thinking Skills as confirmed by this study are practicable means to enhance students' achievement in Mathematics. This therefore, suggests that Critical Thinking Skills serve as a viable means of improving low academic performance in Mathematics. Based on this, effort should be made to formally train teachers of Mathematics the rudiments of Critical Thinking Skills on how to integrating the skills into the school curriculum for learning.

2. Since the national policy on Education included Critical Thinking as one of the objectives of Nigerian education. The curriculum developers, implementors and educational evaluators and school heads should enforce teachers to incorporate Critical Thinking Skills into subject curriculum and classroom experiences. This is one of the option that can produce a citizen that will be prepared to solve the myriad problems of daily living at individual and corporate levels. The dream of ensuring that Nigerians are able to find meaningfully solutions to scientific, technological, economic, social and political problems confronting the nation can be realized.

3. Finally, Critical Thinking should be made compulsory and integrated in all secondary school curriculum, scheme of work, lesson note, lesson plan and in the classroom when teaching and learning take place because the concepts serves as learning and teaching aids and also makes the students understand the concept better . 


\section{References}

[1]. Abiam, P.O and Odok, J.K. (2006). Factors in students' performance in different branches of secondary school Mathematics. Journal of Education and Technology, 1(1), 161-168. (1)

[2]. Adedayo, O.A. (2006). Problems of teaching and learning mathematics in secondary schools.Paper presented at workshop on effective teaching mathematics, LSPSSDC, Magodo,Lagos. (1)

[3]. Barry, S. S., Ada, F.H. \& Jenny, U. (2003). Assessing critical thinking skills. Paper presented at SACS/ COC, annual meeting/ nashville, tennessee tech university. (1)

[4]. Bassey,S.W., Joshua, M.T, \& Asim, A.E (2008). Gender differences and mathematicsperformance of rural senior secondary students in Rivers State, Nigeria. Proceedings of International Conference to Review Research in Science, Technology and Mathematics Education. Munba, India, 2 ( 3), 12-18. of distance education, 20(2), 1-20. (1)

[5]. Charles R. Phillips, PhD, Renae J. Chesnut, EdD, and Raylene M. Rospond(2004). The California Critical Thinking Instruments for Benchmarking, Program. American Journal of Pharmaceutical Education 68 (4) Article 101. 8.

[6]. Facione, P. A. (1990). Critical Thinking: A statement of expert consensus for purposes of Educational Assessment and Instruction: Research Findings and Recommendations. American Philosophical Association. Retrieved from ERIC Document Reproduction Service No. ED 315423. (1)

[7]. Fisher,R.(2003).Teaching thinking: Philosophical enquiry in the classroom. London, continuum. (1)

[8]. Kulbir, S.S. (2006). The teachers of Mathematics. New Delhi: Sternling publishers private Ltd. (1)

[9]. Maduabum, M.A. \& Odili, G.A. (2006). Analysis of students' performance in general Mathematics at SSCE level in Nigeria 1992 - 2002. Journal Research for curriculum teaching 1 (1), 64-68. (1)

[10]. Mansoor, F \&Pezeshki, M.(2012). Manipulating Critical Thinking Skills In Test Taking. International Journal of Education, 4, (1), 153-160. (1)

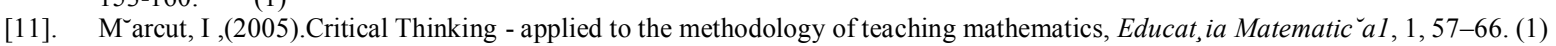

[12]. Osarenren, N. \& Asiedu, A.S. (2007). Counselling implications on the role of the new mathematics teacher in the teaching and learning mathematics. International(1)

[13]. Owolabi, H.O. (2003). The Challenge of Critical Thinking for Curriculum Development and Evaluation in Nigeria. Ilorin Journal of Educational Curriculum, 22 (2) 12-20. (1)

[14]. Schafersman, S.D. (1991). An introduction to Critical Thinking. Retrieved from http://www.freeinquiry.com/critical-thinking.html. (1)

[15]. Scott, J.N. and Markert, R.J. (1994). Relationship between critical thinking skills and success in Pre-clinical courses. Academic medicine, 69, 920-924. (1)

[16]. Semil .R (2006) Enhancing Thinking Skills In The Classroom. Human and Social Sciences Journal 1 (1):28-36(1)

[17]. Swartz, R.J. \& Parkins, S.(1994). Infusing the teaching of critical and creative thinking into content instruction. CA: Critical Thinking Press and software. (1)

[18]. Watson, G. and Glasser, E.M. (1980). Manual; the Watson Glasser critical thinking appraisal, New York: Harcourt Brace.

[19]. Wertheimer, M. (1959). Productive thinking (Enlarged Ed.). New York:Harper \& Row(1) 